CUAJ honours its members and friends who have passed away. We invite colleagues of the deceased to submit brief remembrances. Please limit your notice to 200 words. Send your notice to journal@cua.org or fax it to 514-395-1664.
Cite as: Can Urol Assoc J 2017;11 (6):215. http://dx.doi.org/10.5489/cuaj.4686

\section{Dr. Mostafa Elhilali}

$\mathrm{T}$ he urology community was saddened by the recent and sudden loss of Dr. Mostafa Elhilali, an exceptionally talented urologist and a long-serving member and past-president of the Canadian Urological Association (CUA).

Dr. Elhilali was a world-renowned urologist and specialist in prostatic diseases. His entire career was devoted to improving urological patient care through surgical innovation and improvements in surgical training. As an educator, he influenced the careers of hundreds of urologists, not only in Canada but throughout the world.

Having received his medical training in Egypy, Dr. Elhilali completed his $\mathrm{PhD}$ at McGill University, where he returned 17 years later as Professor and Chairman of the Division of Urology. At McGill, he served as Director of the Division of Urology from 1982-2004 and Director of the McGill University Urology Training Program from 1983-1992.

Dr. Elhilali was an active member of the CUA throughout his distinguished career, serving in multiple capacities, including Committee Chair positions for the CUA research and science programs (1982-1985). He also served on the CUA Nominating Committee and was a member of the CUA Board of Directors in the role of VicePresident and Member-at-Large representative (1990-1994). He served as President of the CUA in 1992-1993.

His dedication to urology was recognized with numerous honours, including the CUA Lifetime Award in 1998. Dr. Elhilali's significant contributions to healthcare were also recognized beyond our discipline; he was the recipient of the prestigious titles of Officer of the Order of Canada in 2002 and the Ordre National du Québec in 2009.

But perhaps his greatest accomplishment is the countless people whose lives have been saved, whose pain and suffering relieved due to his compassionate care. He never refused to review a complex case, provide advice on a difficult problem, or take over the care of the very sick when others could no longer help. He was truly the urologist of last resort.

Those who knew Dr. Elhilali will no doubt cherish the memories of a gifted surgeon and teacher, innovative researcher, urological thought-leader, but most importantly a dear friend. For members who did not know him, rest assured Dr. Elhilali's influence and gifts to urology will live on through his many contributions and protégés. 


\section{IN MEMORIAM}

CUAJ honours its members and friends who have passed away. We invite colleagues of the deceased to submit brief remembrances. Please limit your notice to 200 words. Send your notice to journal@cua.org or fax it to 514-395-1664.
Cite as: Can Urol Assoc J 2017;11 (6):216. http://dx.doi.org/10.5489/cuaj.4687

\section{Dr. Robert Walter Hogarth}

r. Robert Walter Hogarth passed away April 10, 2017. He is survived by his wife, Barbara, and children Sharon (Denis), Walter (Gail), Margaret, and Jeanne (Gilbert), as well as his grandchildren and great grandson.

Dr. Hogarth completed his medical degree at the University of Western Ontario and went on to do his residency in urology at the Montreal General Hospital, becoming a Fellow of the Royal College of Physicians and Surgeons of Ontario, as well as a member of the Canadian Urological Association and the Northeast section of the American Urological Association. He practiced urology until his retirement in 1996.

When he wasn't practicing, Dr. Hogarth maintained the family tree farm his grandfather started, which he later donated to Lakehead University for use by the Forestry Department.

Cite as: Can Urol Assoc J 2017;11(6):216.http://dx.doi.org/10.5489/cuaj.4707

\section{Dr. Clark B. Jamieson}

$\mathrm{D}$ r. Clark Burson Jamieson passed away peacefully on May 2, 2017. He is mourned by his wife of 49 years, Joan, his daughters, Sara and Arleigh, his son-in-law, Russell Hepburn, his two amazing grandchildren, Josephine and Theo, and the many members of his extended family.

Dr. Jamieson received his medical degree from the University of Alberta, did his internship and residency in Winnipeg, and then practiced as a urologist in Prince George for 38 years, before retiring in 2014.

Dr. Jamieson loved the city of Prince George, the people, the medical community, the spirit of the city, and the wilderness that surrounded it. He was always exploring new places and learning new things. He will be terribly missed by his family, friends, colleagues, and the many patients he helped over the years. 